Review

\title{
Quality of meat and meat products produced from southern European pig breeds
}

\author{
Carolina Pugliese *, Francesco Sirtori \\ Dipartimento di Biotecnologie Agrarie, Sezione di Scienze Animali, Università degli Studi di Firenze, Via delle Cascine, 5, 50144, Firenze, Italy
}

\section{A R T I C L E I N F O}

\section{Article history:}

Received 16 May 2011

Received in revised form 27 September 2011 Accepted 30 September 2011

\section{Keywords:}

Autochthonous pigs

Meat quality

Outdoor

Dry-cured products

\begin{abstract}
A B S T R A C T
Genetic and environmental effects on the quality of meat from southern European pig breeds are discussed. In the literature, it is evident that the breeds native to southern Europe have an interesting quality of products with respect to improved pigs. The free-range system increases the value of animal products due to the influence of outdoor rearing on the chemical, physical and organoleptic characteristics of the product. Traditional food products of high quality, such as those obtained from animals reared outdoor, are in high demand. The studies carried out on native pig breeds in southern Europe have focused on various aspects, ranging from studies of population genetics aimed at averting the danger of extinction and reducing inbreeding to studies of the factors affecting the quality of products. The purpose of this review is to analyse the literature on pig breeds native to southern Europe, with particular reference to the effects of genetics and breeding systems on the quality of products.
\end{abstract}

\section{Contents}

1. Introduction . . . . . . . . . . . . . . . . . . . . . . . . . . . . . . . . . . . . . . . . 511

2. The main breeds of native pig in southern European countries

3. The quality of meat and fat . . . . . . . . . . . . . . . . . . . . . . . . . . . . . . . . . . . . . . . 512

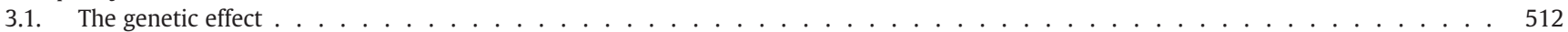

3.2. Environmental effects: the importance of the rearing system . . . . . . . . . . . . . . . . . . . . . . . . . . . . . . 514

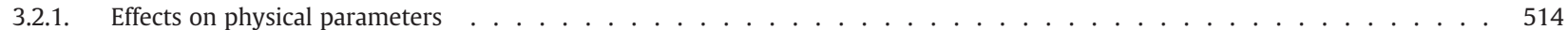

3.2.2. Effects on lipids . . . . . . . . . . . . . . . . . . . . . . . . . . . . . . . . . . . . . . . 514

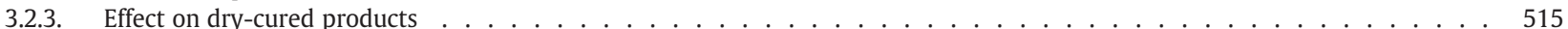

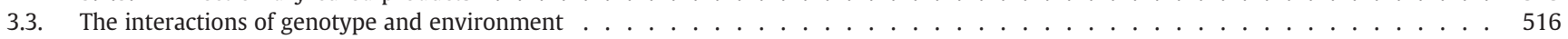

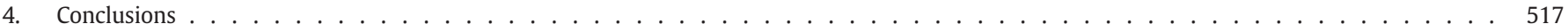

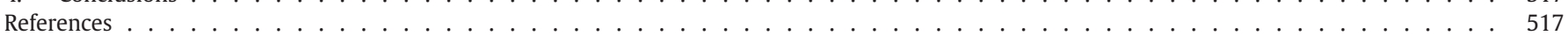

\section{Introduction}

The importance of biodiversity and the recovery of endangered germplasm have been emphasised for a long time, but it wasn't until the 1992 Convention of Rio de Janeiro that experts indicated that the conservation of biological diversity is "a common concern of humankind" and an integral part of the development process at the global level. Strong economic, cultural and scientific motivations are the basis for the recovery of genetic resources.

In the early decades of the last century, there was a wide variety of native pig breeds in southern Europe. The post-war transformations in the agricultural system, the intensification and industrialisation of pig farming, the modification of land use and the massive utilisation

\footnotetext{
* Corresponding author. Tel.: + 39055 3288263; fax: + 39055321216

E-mail address: carolina.pugliese@unifi.it (C. Pugliese).
}

of higher-producing breeds caused native breeds to decline in importance. Most of the breeds native to southern Europe come from small populations and require collective management both for maintenance of the breed and to avoid inbreeding. This is a major issue for the future because most of the native breeds are not presently managed in a secure way. For these reasons, southern European countries spend heavily to support this sector of the agricultural economy.

In some European countries, the typical products from native pigs are a good example of the strong cooperation between public institutions, producers and scientists. Thanks to this synergy, products made from native pigs are well known throughout Europe.

\section{The main breeds of native pig in southern European countries}

Table 1 lists some native breeds reported by the United Nations' Food and Agriculture Organization (FAO) in the Domestic Animal 
Table 1

Local breeds of some Southern Europe countries listed by FAO.

Modified from http://dad.fao.org/.

\begin{tabular}{|c|c|c|c|c|c|c|}
\hline France & Italy & Spain & Portugal & Greece & Slovenia & Croatia \\
\hline Bayeux & Apulo-Calabrese & Celta & Alentejana & Greek & Krskopolje & Black Slavonian \\
\hline Blanc de l'Ouest & Bergamasca nera & Chato Murciano & Bisaro & & & Turopolje \\
\hline Carélie & Casertana & Gochu Asturcelta & & & & \\
\hline Corse & Cinta Senese & Ibérico & & & & \\
\hline Creole & Macchiaiola Maremmana & Ibérico (Dorado Gaditano) & & & & \\
\hline Gallia & Mora Romagnola & Ibérico (Mamellado) & & & & \\
\hline Gasconne & Napoletana Fulva & Ibérico (Negro Entrepelado) & & & & \\
\hline Pie Noir du Pays Basque & Nero dei Lepini & Ibérico (Negro Lampiño) & & & & \\
\hline \multirow[t]{8}{*}{ Porc de Saint Yriex } & Nero dei Monti Dauni Meridionali & Iberico (Retinto) & & & & \\
\hline & Nero Reatino & Ibérico (Torbiscal) & & & & \\
\hline & Nero Siciliano & Manchada de Jabugo & & & & \\
\hline & Parmigiana Nera & Negra Canaria & & & & \\
\hline & Pugliese & Negra Mallorquina & & & & \\
\hline & Sarda & & & & & \\
\hline & Siciliano & & & & & \\
\hline & Suino dei Nebrodi e Madonie & & & & & \\
\hline
\end{tabular}

Diversity Information System (http://dad.fao.org/). According to the FAO database, the breeds listed in the table exist currently, but many are actually extinct or nearly so. Moreover, in each of these countries, only some of the extant breeds have a real chance of survival, primarily related to producing products with high added value.

In Spain, although several native breeds are reared at present, the Ibérico, that is the Spanish generic name for Iberian breeds, is certainly the most famous, and it can be considered the best example of the strong cooperation between public institutions, producers and scientists. Thanks to this synergy, Iberian pig products are renowned throughout Europe. According to Lopez-Bote (1998), over time, and particularly from the 1950 s to 1970 , a number of factors linked to urban development and the intensification of animal production diminished the consistency of Iberian pigs. In recent years, demand for Iberian pig products has increased, which is attributed to a revaluation of traditional, top-quality products.

In Portugal, according to the FAO database, two native pig breeds Bisara and Alentejano, are reared, but actually, Malhado de Alcobaca are more commonly reared (Vicente, Pereira, Carolino, \& Gama, 2006). In recent years, there has been an expansion of pigs native to Portugal, with many changes in production, processing and marketing taking place (Matos, 2000).

In France, the main native breeds are: Blanc de l'Ouest, Limousin, Porc Gascon, Bayeaux, Porc Basque and Nustrale (former Porc Corse). The conservation of these breeds is intended, as in other European countries, to maintain genetic variation within breeds and to obtain economic advantages through the production of high-quality products (Labroue et al., 2000). In fact, the management and recovery of native breeds in France is done primarily to obtain Protected Designations of Origin (PDO) (Lambert-Derkimba, Verrier, \& Casabianca, 2011).

In Italy, of the several native pigs listed by the FAO, only six Apulo-Calabrese, Casertana, Cinta Senese, Mora Romagnola, Nero Siciliano and Sarda - survived the transformations in agriculture that happened in the last century. These breeds have been recognised in the Pedigree Register. The other native populations included in the FAO database have no official recognition (some of them are actually the same breed) and a very high number of populations are declared extinct (Bittante, 2011). The recovery of genetic variability represents an advantage for breeders; they can offer to consumers products with high added value due to the quality of the meat and cured meat products of native breeds. Moreover Italian consumers have an increasing interest in "niche products" (Franci \& Pugliese, 2004).

The Greek pig is a domestic breed that looks like a wild boar, and it survives in the northern areas of Greece. The rearing of this breed is now expanding; during the 1980s, strong competition from "improved" genotypes and crossbreeding with the wild boar nearly caused the breed to become extinct. Greek pigs are generally reared outdoors and grazed in oak forests (Bonanzinga et al., 2010).

In Slovenia, only one native breed is recognised. The Krskopolje, or "blackbelted", originated in Dolenjska, in the south-eastern portion of the country. In 1992, when the herdbook was re-established, there were fewer than 30 sows and only 3 boars. The population today consists of 150 registered sows and 30 boars (Malovrh, Planinc, \& Kovač, 2010). The breed shows good adaptability to poor feeding and environmental conditions. The Krskopolje breed has average fertility, a good appetite and a high growth rate. The breed is known for highquality meat and cured-meat products (Planinc, Malovrh, \& Kovač, 2010).

In Croatia, the main native breed is the Black Slavonian, which was created in the second half of the 19th century. Until the 1950s, it was the most widespread breed in Slavonia, a region in eastern Croatia, and it was used mainly for the production of fat and meat products. Recently, the population was drastically reduced, and in the 1990s, the survival of the breed was endangered. Due to current protection measures, the effective population increased; in 2006, there were 46 boars and 604 sows. The breed is well adapted for outdoor keeping (Karolyi, Luković, \& Salajpal, 2007).

In recent years, the productive performances of southern European native breeds have been investigated by several authors who have taken into account many factors. In this review, the effects of genotype and rearing system will be discussed, as they are the main factors that affect the quality of products from native breeds.

\section{The quality of meat and fat}

\subsection{The genetic effect}

A recent review (Bonneau \& Lebret, 2010) regarding the influence of production systems on the quality of pork, identified 84 pork production systems in 23 European countries, of which 40 were considered "conventional", and the remaining 44 were regarded as "differentiated", on the basis of several claims. In one third of the "differentiated" production systems, native breeds were used and, most often, their meat was found to be of higher quality than the meat of conventional "improved" genotypes.

The term "improved" generally refers to the cosmopolitan pig breeds that have undergone genetic improvements aimed at enhancing their productive performance, according to industrial criteria. Some scientific studies have compared native pigs with "improved" ones, so it is possible to verify the actual gap between the two genetic types and to evaluate the effects of genetic improvement in swine during the last half century. Other trials have compared the native 
breeds to one another (Barone, Castellano, Colatruglio, Zullo, \& Matassino, 2007; Fortina et al., 2005; Labroue et al., 2000; Porcu et al., 2007; Zullo et al., 2007).

A comparative review of trials is difficult and should be interpreted with caution, because the studies were carried out under different conditions, particularly when animals were reared outdoors. However, an overview of the principal characteristics of these breeds and the differences between them can be useful.

Table 2 gives the halothane gene frequencies of several native breeds. The halothane gene is a recessive gene that affects an animal's susceptibility to stress. This stress-syndrome is due to a mutation in the gene controlling the calcium release channel (Ryanodine receptor, RYRl) of the sarcoplasmic reticulum. This gene causes a higher incidence of pale, soft, and exudative (PSE) meat (Zhang, Kuhler, \& Rempels, 1992).

Generally, the southern European pig breeds seem not to have the halothane gene, as reported by Matassino et al. (2000) in Calabrese, Casertana and Nero Siciliano pigs and by Ramos et al. (2000) in Manchado de Jabugo breeds. However, in the Nero Siciliano (Russo et al., 2004) and Cinta Senese breeds (Crovettti, Bozzi, Nardi, Franci, \& Fontanesi, 2007), a very low frequency $(0.01 \%$ and $0.02 \%$, respectively) of T alleles at the RYR1 locus was found; the frequency was also very low (0.07) in the Portuguese breeds (Pinheiro et al., 2007). In French native breeds, a large variation in frequency (from 0 to $44 \%$ ) of the same halothane-sensitive allele was found by Labroue et al. (2001). This investigation indicates the possibility of some introgression of this gene from the commercial breeds (Landrace or Pietrain) into several native breeds and suggests the importance of recovering the primitive germplasm and of monitoring the native populations to avoid indiscriminate crossbreeding that happened during a period of severe size reduction.

Among the qualitative traits of meat, evaluating intramuscular fat content (IMF) seems to be the best way to separate native pigs from "improved" ones (Table 3). Cinta Senese (Franci et al., 2005) and Nero Siciliano breeds (Pugliese et al., 2004) had IMF higher than $3 \%$ in the Longissimus, a muscle with moderate fatness; the corresponding value in Large White pigs was less than 1\% (Franci et al., 2005). In Casertana meat, IMF content was nearly 4\% (Zullo, Barone, Colatruglio, Girolami, \& Matassino, 2003). Labroue et al. (2000) found significantly higher levels of IMF in Basque, Gascon, Limousin and Blanc de l'Ouest pigs than in Large White pigs. It is well known that in some muscles of native breeds, the IMF can reach $10 \%$, as found in Iberian (Mayoral et al., 1999), Chato Murchano (Poto, Galián, \& Peinado, 2007) and Corsican pigs (Coutron-Gambotti, Gandemer, \& Casabianca, 1998) reared outdoors. Fernàndez, Garcìa-Gasco, De Pedro, Siliò, and Rodriguez (2007), analysing 2664 samples of Longissimus dorsi muscle from Iberian pigs, found that IMF values ranged from $3.27 \%$ to $29.21 \%$. Considering that the organoleptic traits of raw meat are linked to IMF and that $2-2.5 \%$ IMF is believed to be the minimum acceptable level (Affentranger, Gerwig, Seewer,

Table 2

Halothane gene frequency.

\begin{tabular}{lll}
\hline Author & Breeds & Halothane gene (frequency) \\
\hline Matassino et al. (2000) & Casertana & Free \\
& Nero Siciliano & Free \\
& Apulo Calabrese & Free \\
Ramos et al. (2000) & Manchado de Jabugo & Free \\
Labroue et al. (2001) & Basque & Free \\
& Bayeux & 0.44 \\
& Gascon & 0.01 \\
& Limousine & 0.05 \\
Russo et al. (2004) & Blanc de l'Ouest & 0.34 \\
Crovetti et al. (2007) & Nero Siciliano & 0.01 \\
Pinheiro et al. (2007) & Cinta Senese & 0.02 \\
& Bisaro & 0.07 \\
\hline
\end{tabular}

Table 3

Intramuscular fat (IMF) content according to genetic type.

\begin{tabular}{lll}
\hline Author & Breeds & IMF $\left(\%\right.$ on w.b. ${ }^{\text {a }}$ ) \\
\hline $\begin{array}{l}\text { Mayoral et al. (1999) on } \\
\text { Longissimus lumborum (LL) }\end{array}$ & Ibérico & $\sim 10$ \\
$\quad$ and Biceps femoris (BF) & & \\
Labroue et al. (2000) (on LL) & Basque & 3.9 \\
& Gascon & 3.2 \\
& Limousine & 3.4 \\
Karolyi et al. (2007) & Blanc de l'Ouest & 2.9 \\
Zullo et al. (2003) (means of & Black Slavonian & $\sim 6$ \\
$\quad$ Casertana & $\sim 4$ \\
Salvatori et al. (2008) on LL & Casertana & $\sim 2$ \\
Fortina et al. (2005) on & Casertana & $\sim 5$ \\
$\quad$ Longissimus Thoracis (LT) & & \\
Poto et al. (2007) on LL & Chato Murciano & $\sim 10$ \\
Franci et al. (2005) on LL & Cinta Senese & $>3$ \\
Coutron-Gambotti et al. (1998) & Corsican (on BF) & 8.2 \\
Fernández et al. (2007) on LL & Ibérico & $\sim 10$ (minimum 3.27- \\
Fortina et al. (2005) on LT & Mora Romagnola & $\sim 6$ \\
Pugliese et al. (2004) on LT & Nero Siciliano & $>3$ \\
\hline
\end{tabular}

a w.b. = weight basis

Schwiirer, \& Kiinzi, 1996), it is evident that genetic improvement to produce leaner meat in swine reduces the meat quality.

According to Gandemer (2002), IMF affects several quality traits of dry-cured hams, especially of slices. In particular, the colour and tenderness are related to IMF: redness, brightness scores and the shear force of hams decrease as IMF increases. Moreover, hams produced from genotypes with high levels of IMF have more intense fat aroma, because intramuscular triacylglycerols are a good solvent for most aromatic compounds. The higher the intramuscular triacylglycerol content of muscle, the more the aromatic compounds will be trapped in the ham.

The effect of genetic type on product quality was studied by comparing the native breeds with the "improved" ones as well as by comparing the former against their crosses with pure breeds.

As for the fatty acid composition of lipids (Table 4) the comparison between native and improved breeds, or their crosses, is reported. The comparison of trials is difficult because of the variability of depots and localisations analysed in the respective studies. Taking into account those studies where the comparisons between native and

Table 4

Fatty acid composition according to genetic type (\% of the total fatty acids).

\begin{tabular}{|c|c|c|c|c|}
\hline Author & Breed & SFA & MUFA & PUFA \\
\hline \multicolumn{5}{|l|}{ Comparison among pure breeds } \\
\hline \multirow{5}{*}{$\begin{array}{l}\text { Labroue et al. ( } 2000) \text {, on fresh } \\
\text { subcutaneous fat }\end{array}$} & Basque & $43.1 \mathrm{a}$ & $45.2 \mathrm{a}$ & $11.7 \mathrm{a}$ \\
\hline & Gascon & $46.6 \mathrm{~b}$ & $43.5 b$ & $9.9 \mathrm{~b}$ \\
\hline & Limousine & $46.3 \mathrm{~b}$ & $43.9 b$ & $9.9 \mathrm{~b}$ \\
\hline & Blanc de l'Oueste & $41.3 \mathrm{~b}$ & $46.8 \mathrm{a}$ & $12.0 \mathrm{a}$ \\
\hline & Large White & $41.7 \mathrm{c}$ & $42.4 \mathrm{c}$ & $16.0 \mathrm{c}$ \\
\hline \multirow{2}{*}{$\begin{array}{l}\text { Franci et al. (2005), on fresh } \\
\text { subcutaneous fat }\end{array}$} & Cinta Senese & $36.2 \mathrm{a}$ & $50.3 a^{*}$ & $10.4 \mathrm{a}$ \\
\hline & Large White & $37.6 \mathrm{~b}$ & $48.5 b^{*}$ & $11.1 \mathrm{~b}$ \\
\hline \multirow{2}{*}{$\begin{array}{l}\text { Madonia et al. (2007), } \\
\text { on salami }\end{array}$} & Nero Siciliano & 33.39a & $53.29 a$ & $13.33 a$ \\
\hline & Large White & $37.71 b$ & $47.42 \mathrm{~b}$ & $14.87 b$ \\
\hline \multicolumn{5}{|c|}{ Comparison between pure and cross breeds } \\
\hline \multirow{2}{*}{$\begin{array}{l}\text { Carrapiso et al. (2003), on } \\
\text { fresh subcutaneous fat }\end{array}$} & Ibérico & 36.91 & $49.78^{*}$ & $7.72^{* *}$ \\
\hline & Ibérico $\times$ Dur & 38.21 & $48.87^{*}$ & $7.89^{* *}$ \\
\hline \multirow{2}{*}{$\begin{array}{l}\text { Salvatori et al. (2008), on fresh } \\
\text { subcutaneous fat }\end{array}$} & Casertana & 39.60 & $41.31 \mathrm{a}$ & $17.84 a$ \\
\hline & Casertana $\times$ LW & 39.72 & $38.41 \mathrm{~b}$ & $21.12 b$ \\
\hline \multirow{2}{*}{$\begin{array}{l}\text { Coutron Gambotti et al. } \\
\text { (1998), on fresh BF }\end{array}$} & Corsican & $36.9 \mathrm{a}$ & $57.4 a$ & 5.6 \\
\hline & Corsican $\times$ LW & $39.6 b$ & $54.4 \mathrm{~b}$ & 6.0 \\
\hline \multirow{2}{*}{$\begin{array}{l}\text { Elias et al. (2000), on dry- } \\
\text { cured subcutaneous fat }\end{array}$} & Alentejano & 43.2 & $47.7^{*}$ & $5.1^{* *}$ \\
\hline & Alentejano $\times(\mathrm{LW} \times \mathrm{D})$ & 43.7 & $46.3^{*}$ & $5.7^{* *}$ \\
\hline
\end{tabular}

On the same column, within each trial, means with different letters differ significantly. * Only oleic acid.

** Only linoleic acid. 
"improved" breeds (or their crosses) were carried out under the same rearing conditions, it is possible to conclude that both French (Coutron-Gambotti et al., 1998; Labroue et al., 2000) and Italian (Franci et al., 2005; Madonia et al., 2007; Salvatori et al., 2008) native pigs show a high predisposition to depot of MUFA, mainly oleic acid, whereas "improved" pigs contain higher quantities of saturated fatty acids or, in the case of extreme leanness, of linoleic acid. The highest level of monounsaturated fatty acid in native breeds could be a consequence of differences in de novo lipid synthesis and turnover. Moreover, their capacity to deposit monounsaturated fatty acids increases with age (Edwards, 2005).

These differences are attenuated when the comparison is between native breeds and crossbreeds, as demonstrated by Elias, Sanabria, and Tirapicos-Nunes (2000) and Carrapiso, Bonilla, and Garcìa (2003) on Alentejano and Iberian pigs, respectively.

The practice of crossbreeding is widely used in several regions. According to Bonneau and Lebret (2010), the eating quality of crossbreeds is usually between that of the parent breeds and higher than that of conventional pigs. In southern Europe, local breeds are often crossed with selected breeds to exploit additive and nonadditive genetic variances, as in the production of Corsican $\times$ Large White (Coutron-Gambotti et al., 1998) and Iberian $\times$ Duroc (Carrapiso et al., 2003) pigs.

Crossing with the Duroc breed is often used to improve the productivity of the animals without greatly affecting their hardiness or reducing their level of IMF. This is particularly important for processed products, such as dry hams, where marbling is a recognised criterion of quality (Edwards, 2005).

In the production of Iberian dry-cured ham, the rule of the Protected Designation Origin (PDO) allowed, until now, crossbreeding between Iberian and Duroc breeds. As reported by Carrapiso et al. (2003), the pigs crossbred from Iberian and Duroc pigs are usually used to improve some productive characteristics, and Iberian pigs with up to $50 \%$ Duroc genes can currently be used in the production of Iberian hams with PDO.

The Duroc breed, therefore, could play a key role in all types of outdoor rearing systems, where the organoleptic benefits conferred by its genetic predisposition to deposit IMF are widely recognised and valued (Edwards, 2005).

In other situations, the crossbreeding of native breeds, such as Cinta Senese pigs, with conventional ones is not permitted by the PDO rule.

Some comparative studies were also conducted on the sensory traits of dry-cured products to evaluate the differences between several native Italian breeds (Zullo et al., 2007) and between French and Spanish pigs (Lebecque, Giraud, Amblard, Lucan, \& Poma, 2007). Labroue et al. (2000), in a comparison between native French breeds and Large White pigs, found the best sensory traits in the meat of native pigs; they justify this result with reference to the IMF levels in native pigs. Girard, Bout, and Salort (1988) stressed the positive relationship between meat flavour and intramuscular fat percentage. It must be underlined that these comparisons between breeds were not always carried out under the same rearing conditions.

\subsection{Environmental effects: the importance of the rearing system}

The environmental effects on the quality of products from native breeds should be broadly considered. Due to the rearing systems that characterise the native breeds (almost always outdoors), the environmental effects on product quality are the combined result of both the farming system and the feeding regimen.

Southern European pig breeds are reared with different modalities that range from systems that, even if outdoors, supplement the total food supply with concentrate, to more extensive systems where the fattening phase is carried out using only the resources of the natural environment. The latter is typical of the "Montanera" system, where
Iberian pigs are fattened in the "Dehesa" (Lopez-Bote, 1998) and the native Portuguese pigs in the "Montados" (Tirapicos-Nunes, 2007).

\subsubsection{Effects on physical parameters}

As discussed by Jonsäll, Joansson, and Ludström (2001), the effects of rearing systems on the physical parameters of meat from "improved" pigs are contradictory. Even in studies of native breeds, reported data are not always consistent. The higher value of shear force recorded in Cinta Senese pigs reared outdoors (Pugliese et al., 2005) was probably due to their older age at slaughter rather than to the rearing system; this hypothesis is confirmed by the fact that no differences in meat tenderness were found between Nero Siciliano pigs reared outdoors and those reared indoors that were slaughtered at the same age (Pugliese et al., 2004). The older age at slaughter of Cinta Senese pigs reared outdoors may also be the reason for their higher values of CIELab a* and, consequently, of chroma, with respect to pigs reared indoors. In fact, as reported by Mayoral et al. (1999), myoglobin concentration in pig muscle increases with ageing. Very few differences were found by Lopez-Bote et al. (2008) in drip loss, heme pigment concentration, CIELab colour or rheological properties in Psoas major muscle between sedentary and free-range Iberian pigs; they suggest that the intensity of the exercise is not high enough to affect fresh meat quality characteristics.

The effects of the rearing system on physical parameters have been studied with Magnetic Resonance Imaging (MRI). Pérez-Palacios et al. (2010) studied the MRI-based texture characteristics of dry cured Iberian hams from pigs fed different diets (acorn plus grass versus high oleic acid concentrate), and it seems that ham identification from Iberian pigs fed different diets could be achieved by this analysis.

\subsubsection{Effects on lipids}

As previously indicated, the outdoor rearing of native pigs is carried out almost entirely in forests, so it is very different from the classic outdoor system used for "improved" pigs, where commercial feed is the basis of the diet. Consequently, the effects of food source, especially on the quality of lipids, are very strong (Tables 5 and 6).

Lipids of adipose tissues largely vary both quantitatively and qualitatively according to the rearing system (Gandemer, 2002); moreover adipose tissue reflects the diet much better than other tissues that are subject to a more strict control.

As reported by various authors (Andrés et al., 2001; Cava, Ruiz, Ventanas, \& Antequera, 1999a; Cava, Ventanas, Tejeda, Ruiz, \& Antequera, 2000; Coutron-Gambotti et al., 1998; Diaz, Garcia Regueiro, Casillas, \& De Pedro, 1996), the lipids of pigs reared in woods are characterised by a high level of unsaturated fatty acids (Table 5). CoutronGambotti et al. (1998) found a higher percentage of PUFA and MUFA fatty acids in Corsican pigs fed chestnuts than those fed a commercial diet. In Iberian pigs fed acorns, higher MUFA (primarily oleic acid) and lower SFA levels (primarily palmitic and stearic acids), were found both in intramuscular fat (Andrés et al., 2001; Cava et al., 1999a, 2000) and back-fat (Dìaz et al., 1996). This result is consistent with the data on Italian breeds, such as Nero Siciliano (Chiofalo, Lo Presti, Piccolo, \& Arena, 2007) and Cinta Senese (Pugliese et al., 2005). The latter, in addition, showed higher PUFA levels when reared outdoors, probably because of the consumption of chestnuts and acorns during fattening. The same results were found by Sirtori, Pugliese, Parenti, D'Adorante, and Franci (2011) in Cinta Senese after substituting concentrate for chestnut. It is well known that chestnuts have higher concentrations of polyunsaturated fatty acids than acorns (CoutronGambotti et al., 1998; Lopez-Bote, 1998).

Another source of PUFA in free-range conditions is the grass that, as reported by Muriel, Ruiz, Ventanas, and Antequera (2002), is characterised by high levels of linoleic acid. These authors concluded that free-range rearing leads to increased levels of total n-3 PUFA in 
Table 5

Effect of rearing system on the fatty acid composition of fresh meat and fat (\% of the total fatty acids).

\begin{tabular}{|c|c|c|c|c|}
\hline Author & Rearing system & C18:1 & C18:2 & C18:3 \\
\hline \multirow[t]{2}{*}{ Diaz et al. (1996) on subcutaneous fat of Ibérico } & Acorn + grass & $57.1 \mathrm{a}$ & $9.4 a$ & \\
\hline & Concentrate & $47.4 \mathrm{~b}$ & $8.3 \mathrm{~b}$ & \\
\hline \multirow{2}{*}{ Pugliese et al. (2005) on subcutaneous fat Cinta Senese } & Pasture on wood (chestnut + acorn + grass) & $52.8 \mathrm{a}$ & $11.6 a$ & $0.87 a$ \\
\hline & Concentrate & $50.3 b$ & $9.5 b$ & $0.32 b$ \\
\hline \multirow[t]{2}{*}{ Coutron-Gambotti et al. (1998) on subcutaneous fat of Corsican } & Chestnut only & 49.1 & $7.3 a$ & $0.9 \mathrm{a}$ \\
\hline & concentrate & 47.5 & $5.2 \mathrm{~b}$ & $0.6 \mathrm{~b}$ \\
\hline \multirow[t]{2}{*}{ Sirtori et al. (2011) on subcutaneous fat of Cinta Senese } & Chestnut only & $28.1 a^{*}$ & $6.5 a^{*}$ & $0.41 a^{*}$ \\
\hline & concentrate & $25.5 b^{*}$ & $5.5 b^{*}$ & $0.24 b^{*}$ \\
\hline \multirow{2}{*}{ Zumbo, Lo Presti, et al. (2007) on LL of Nero Siciliano } & Acorn only & $50.5 a$ & $4.7 \mathrm{a}$ & $0.23 a$ \\
\hline & Barley & $43.9 \mathrm{~b}$ & $7.1 \mathrm{~b}$ & $0.90 \mathrm{~b}$ \\
\hline \multirow[t]{2}{*}{ Andrés et al. (2001) on BF of Ibérico } & Acorn + grass & $53.4 a$ & 5.6 & 0.3 \\
\hline & Concentrate & $50.7 \mathrm{~b}$ & 6.4 & 0.3 \\
\hline \multirow[t]{2}{*}{ Cava et al. (2000a) on BF of Ibérico } & Acorn + grass & $55.1 \mathrm{a}$ & 5.66 & 0.68 \\
\hline & Concentrate & $51.9 \mathrm{~b}$ & 5.02 & 0.64 \\
\hline
\end{tabular}

On the same column, means with different letters differ significantly.

* Fatty acid composition as g/100 of DM.

neutral and polar lipids and of individual n-3 PUFA, including EPA and DHA. The effect of outdoor pasture on acorns is not the same as the administration of acorn in a confined rearing system. Zumbo, Lo Presti et al. (2007) found higher levels of MUFA and lower levels of PUFA in the Longissimus lumborum of Nero Siciliano pigs fed acorns, than those fed barley (Table 6). In this trial the acorn was administrated and not pastured so the lower content of PUFA in pig fed acorn was due to the lower content of PUFA in this fruit with respect to barley.

Both $\alpha$ - and $\gamma$-tocopherol are provided by the free-range system and prevent lipid oxidation. Rey, Daza, Lòpez-Carrasco, and LòpezBote (2006) reported that no significant differences were detected in the concentrations of $\gamma$-tocopherol between groups fed acorns or those fed acorns and grass, either free-range or in confinement; this would indicate that the rearing system did not affect the accumulation of this compound in tissues. On the contrary, the $\alpha$-tocopherol accumulation in the muscle depends on the rearing condition. As reported by Rey and Lòpez-Bote (2001), muscle Longissimus from pigs fed extensively had higher concentration of $\alpha$-tocopherol than those from pigs fed in confinement. This can be attributed to the relatively high concentration of $\alpha$-tocopherol in grass. Also in Alentejano pigs, Neves, Freitas, Martins, and Nunes (2007) found higher levels of $\alpha$-tocopherols in pigs reared extensively than in those reared intensively.

More recently, attention has been focused on the levels of triacylglycerols (TGs) in lipids. As reported by Petrón, Muriel, Timón, Martín, and Antequera (2004), TGs represent the chemical forms in which the fatty acids exist in adipose tissues and, even if they are not exclusive in this tissue, some of the physical and chemical properties of adipose tissues are related to the composition of TGs in the tissue.

Petrón et al. (2004) found that hams made from pigs pastured in woods and fed acorns and grass contained more OOO, OLL and OOL than pigs fed foodstuffs with the most saturated TGs (PPL, PPO, PSO,

Table 6

Effect of rearing system on fatty acid composition of dry-cured ham (\% of the total fatty acids).

\begin{tabular}{lllll}
\hline Authors & Rearing system & C18:1 & C18:2 & C18:3 \\
\hline Pérez-Palacios et al. (2010) on & Acorn + grass & $53.2 \mathrm{a}$ & $6.96 \mathrm{a}$ & $0.64 \mathrm{a}$ \\
BF of Ibérico & H.O. concentrate & $48.8 \mathrm{~b}$ & $5.75 \mathrm{~b}$ & $0.27 \mathrm{~b}$ \\
Cava et al. (1999b) on BF of Ibérico & Acorn + grass & $54.4 \mathrm{a}$ & 5.58 & 0.67 \\
& Concentrate & $51.9 \mathrm{~b}$ & 5.02 & 0.64 \\
Pugliese et al. (2009) on subcutaneous & Acorn & $50.8 \mathrm{a}$ & $12.2 \mathrm{a}$ & 0.8 \\
fat of Cinta Senese & Chestnut & $48.4 \mathrm{~b}$ & $13.6 \mathrm{~b}$ & 1.0 \\
& Concentrate & $46.2 \mathrm{c}$ & $14.6 \mathrm{~b}$ & 0.84
\end{tabular}

On the same column, means with different letters differ significantly.

* High oleic content concentrate.
PPS and SSO), where P, O, L and S are Palmitic, Oleic, Linoleic and Stearic acids, respectively. The higher levels of saturated fatty acids of TGs in pigs fed commercial mixture has also been demonstrated in Iberian fresh ham by Díaz et al. (1996) and by Tejeda, Gandemer, Antequera, Viau, and García (2002). Riaublanc, Gandemer, Gambotti, Davenel, and Monin (1999) found higher levels of POL and OOL in Corse pigs fed chestnuts than in those fed a mixture.

\subsubsection{Effect on dry-cured products}

The main differences between cured products from southern Europe and those from northern Europe are due to the processing techniques used. As reported by Flores (1997), typical Mediterranean products are made with a slow curing process, where salt is one of the main ingredients in the curing process; salt levels in meat products may vary between $3 \%$ and $6 \%$. Salt addition is essential for microbiological stability, development of optimum structure and for imparting a salty taste. Moreover, salt affects the generation of volatile compounds through its influence on chemical and biochemical reactions such as lipolysis and proteolysis (Andrés, Cava, Ventanas, Muriel, \& Ruiz, 2004). Despite this, in recent decades, even in regions of southern Europe, the trend is to decrease the percentage of salt in cured products, especially dry-cured hams, for dietary reasons. Several studies of salt in meat curing have been carried out on cured products from native pigs, such those of Corsican, currently Nustrale (Coutron-Gambotti, Gandemer, Rousset, Maestrini, \& Casabianca, 1999), and Iberian breeds (Andrés et al., 2004; Martín, Córdoba, Antequera, Timón, \& Ventanas, 1998).

Other important and significant sources of differentiation between southern and northern European cured products are the breeds used (Dirinck, Van Opstaele, \& Vandendriessche, 1997) and the methods by which they are reared. The latter has been the most investigated because of its strong effect on product quality.

The effects of the extensive rearing system on the fatty acid composition of seasoned products have been studied by several authors (Table 6). Cava, Ruiz, Ventanas, and Antequera (1999b) reported high concentrations of oleic acid in Iberian ham, promoted by acorn pasturing, that, together with the typical marbling of the meat, is considered essential for appropriate ripening and flavour development of dry-cured products. In some cases, the effects of pasture in woods on the fatty acid profile were stronger in dry-cured products than in fresh meat. In a comparison between Iberian pigs reared outdoors with free access to acorns and grass and animals fed on oleic acidenriched concentrate, Pérez-Palacios et al. (2010) found more differences in the fatty acid composition of the Biceps femoris muscle in dry-cured hams than those found in fresh Biceps femoris from the same animals (Pérez-Palacios, Ruiz, Tejeda, \& Antequera, 2009). 
Similar results were found in the fatty acid profiles of dry-cured ham from Cinta Senese pigs reared in woods (Pugliese et al., 2009), where higher differences in MUFA content were found than in the fresh fat of the same animals (Pugliese et al., 2006).

Many studies have been carried out on the effects of the rearing system on the volatile compounds in dry-cured products as identified by gas chromatography-mass spectrometry (GC-MS). In the fresh and seasoned lard of Nero Siciliano pigs (Zumbo, Di Rosa, Lo Presti, Pruiti, \& Piccolo, 2007), in salami (Zumbo et al., 2007) and in dry-cured ham (Pugliese et al., 2009) from Cinta Senese pigs, the feeding regimen (acorns versus concentrate) had a significant effect on the levels of volatile compounds. The effects of the rearing system on the volatile compounds in Iberian ham have been studied (Carrapiso, Jurado, Timòn, \& Garcìa, 2002; Cava et al., 1999b; Jurado, Carrapiso, Ventanas, \& Garcìa, 2009; Jurado, Garcìa, Timòn, \& Carrapiso, 2007; Lopez et al., 1992), but contradictory results have been reported.

Comparison between studies is difficult because of the differences in extraction techniques, in the characteristics of raw material and, in the case of dry-cured products, in the ripening conditions. As shown by Jurado et al. (2007), there are a number of factors related to the rearing system that could influence the type and level of the volatile compounds, such as the composition of the concentrate and the length of the grazing period. These factors could cause considerable heterogeneity in the results. Up to now, the rearing system has had a significant effect on the aromatic compounds when the composition of the feed is clearly different.

The difficulty inherent in characterising the aromatic compounds in cured products is also due to the fact that a limited number of volatile compounds contribute to the aroma of the product. Further, these molecules do not contribute equally to the overall flavour profile of a sample, hence, a large GC peak area generated by a chemical detector does not necessarily correspond to high odour intensities, due to differences in intensity/concentration relationships. Moreover, the interaction of flavour molecules with each other, and with other food constituents must also to be considered (d'Acampora Zellner, Dugo, Dugo, \& Mondello, 2008). Over the last years, further analytical techniques for detecting volatile compounds have been developed. One of these is gas chromatography associated with olfactometry (GC-O) that can be used to identify odour-active components in complex mixtures through specific correlation with the chromatographic peaks of interest; this is possible because the eluted substances are perceived simultaneously by two detectors, one of them being the human olfactory system. Consequently, GC-O provides not only an instrumental but also a sensory analysis (d'Acampora Zellner et al., 2008).

In Iberian ham, significant differences in the olfactometric profiles were found between pigs fed acorn and those fed commercial feedstuffs, even if differences in odour were caused by variations in the concentrations of the same odour-active compounds and not to a single volatile compound that could be used as a marker of a specific feeding system (Carrapiso et al., 2002).

To explain how some chemical characteristics, affected by the rearing system, can influence the sensorial traits of dry-cured products, many researchers have recently focused on the relationships between sensorial traits, lipid composition and volatile compounds.

Carrapiso et al. (2003), with regard to the relationship between sensory profile and the fatty acid composition of subcutaneous fat, found that palmitic and oleic acids were the most significantly correlated to the largest number of sensory traits. Moreover, large correlations appeared between either stearic or oleic acids and the brightness, oiliness, juiciness, sweetness, fat hardness and cured aroma of Iberian dry-cured ham.

As reviewed by Gandemer (2009), positive aroma notes, such as "cured ham" or "aged", have been correlated either with branched aldehydes arising from amino-acid degradation or with methylketones arising from lipid oxidation; a rancid aroma is correlated with oxidation products, mainly with aldehydes, such as nonanal and 2-hexanal.

Garcìa-Gonzáles, Tena, and Aparicio (2009) and Garcìa-Gonzáles, Tena, Aparicio-Ruiz, and Morales (2008) conducted a study on the relationship between odour, flavour attributes and volatile compounds in Iberian hams from diverse geographical origins. An example of these relationships is reported in Table 7.

\subsection{The interactions of genotype and environment}

In the extensive pig production of southern Europe, the interactions of genotype and environment result in measurable effects on pig meat quality (Edwards \& Casabianca, 1997).

These strong interactions are well exploited for Iberian pigs, which are reared outdoors in Mediterranean forests such as La Dehesa, which is composed mainly of evergreen oaks (Quercus ilex), cork oaks (Quercus suber), gall oaks (Quercus lusitanica), arbutus (Arbutus) and heath (Ericeus). As reported by Lopez-Bote (1998), the Iberian pig and La Dehesa form an inseparable unit, so that the persistence of $\mathrm{La}$ Dehesa is possible due to the extensive exploitation of Iberian pigs and vice versa. The whole productive cycle of the animals is planned so that they are physiologically capable of utilising La Dehesa during the late fattening phase. Consequently, Iberian dry-cured ham is classified in several categories according to the rearing conditions of the animals. The Spanish Ministry of Agriculture, Fishery and Food enacted a law to regulate the market for Iberian meat products. This regulation establishes, as a function of the feeding background during the fattening period of the pigs, four commercial categories for Iberian dry-cured meat products, including pigs reared outdoors with free access to natural resources (acorns and grass), animals fed on acorns and grass but supplemented with concentrates, pigs fed outdoors with concentrates, or animals reared in confinement and fed commercial diets (Pérez-Palacios et al., 2009).

To regulate the market for Iberian meat products, last decade, the proportions of the major fatty acids (palmitic, stearic, oleic and linoleic acids) in subcutaneous fat have been used to classify Iberian pigs by their feeding backgrounds during fattening (Pérez-Palacios et al., 2010). In this regard, inspection controls were carried out based upon "on farm" inspector visits and lipid analyses performed on one fat sample taken from a group of animals from the same producer. That system is very time consuming and expensive, and it is not objective enough to fulfil the increasing demands from regional, national, and international markets (Pérez-Marín, de Pedro Sanz, Guerrero-Ginel, \& Garrido-Varo, 2009). For these reasons, many studies have been carried out to find new, innovative methods of traceability, using techniques such as near-infrared spectroscopy (NIRS) (Pérez-Marín et al., 2009), an electronic nose (Garcia et al., 2003) or neophytadiene content (Tejeda, Antequera, Martin, Ventanas, \& Garcìa, 2001).

The rearing of Iberian pigs is a good example of the interaction between animals and their environment, but there are other cases in which this strong link is used to enhance the quality of the product. For example, fresh meat from the Cinta Senese breed has recently

Table 7

Relationship between sensory attributes and volatile compounds qualifying dry-cured hams.

\begin{tabular}{ll}
\hline Attributes & Selected volatiles \\
\hline Acorn odour & Benzaldehyde, 2-heptanone, 3-methylbutanal \\
Acorn flavour & 3-methyl butanal, hexanol, 3-methyl butanol, 2-nonanone \\
Rancid odour & Hexanal, pentanol, hexanol \\
Rancid taste & 3-methylbutanal, hexanol, octanol \\
Fat rancid flavour & Octanol, 3-methylbutanal, limonene \\
Fat pungent flavour & Octanol, limonene \\
\hline
\end{tabular}


obtained the PDO label, which requires that animals be reared outdoors. PDO applications have recently been submitted for the Nero Siciliano and Nustrale pigs.

In all the rearing systems discussed here, the main objective is to exploit the interactions of genotype and environment to reach the highest quality of the products, according to its widest meaning. As reported by Edwards (2005), the product quality is not only related to attributes directly and objectively measurable but also to secondary attributes, such as animal welfare, environmental impact, traceability or safety aspects, which are increasingly appreciated by consumers.

\section{Conclusions}

This review of the literature shows a strong and growing interest by the scientific community in the recovery of native pig breeds and enhancement of their products.

Native pigs are a valuable genetic reserve that can be used to recover the organoleptic properties of pig-meat, properties that were lost because of severe selective programmes undertaken to quantitatively improve pig production.

Analysing the current situation it is emerging that:

- Native breeds, if properly reared for the environmental context, can have a real chance of recovery and survival. This last point is crucial. Because native breeds are reared outdoors in almost all cases, it is important that the system adopted is respectful of the ecosystem

- The quality of the products of native breeds, objectively detectable, can lose meaning if it is not placed in a context of overall quality that considers even the quality of the process.

- A number of these breeds are in search of added value through the PDO (already obtained or applied) supply chain, requiring specifications based upon the particular genotype and providing guaranties on the market.

\section{References}

Affentranger, P., Gerwig, C., Seewer, G. J. F., Schwiirer, D., \& Kiinzi, N. (1996). Growth and carcass characteristics as well as meat and fat quality of three types of pig under different feeding regimens. Livestock Production Science, 45, 187-196.

Andrés, A. I., Cava, R., Mayoral, A. I., Tejeda, J. F., Morcuende, D., \& Ruiz, J. (2001). Oxidative stability and fatty acid composition of pig muscles as affected by rearing system, crossbreeding and metabolic type of muscle fibre. Meat Science, 59, 39-47.

Andrés, A. I., Cava, R. Ventanas, J., Muriel, E., \& Ruiz, J. (2004). Lipid oxidative changes throughout the ripening of dry-cured Iberian hams with different salt contents and processing conditions. Food Chemistry, 84, 375-381.

Barone, C. M. A., Castellano, N., Colatruglio, P., Zullo, A., \& Matassino, D. (2007). Rheological characteristics of dry cured ham of four Italian autochthonous genetic types of pig. Option Mediterraneenes, 76, 197-200

Bittante, G. (2011). Italian animal genetic resources in the Domestic Animal Diversity Information System of FAO. Italian Journal of Animal Science, 10, 151-158.

Bonanzinga, M., Franci, O., Cappè, F., Sirtori, F., Crovetti, A., Esposito, S., et al. (2010, October 14-16). The breeding of the main local pig breeds in Mediterranean Europe. Proceedings of the 6th International Symposium on the Mediterranean Pig, Cordoba, Spain (pp. 24).

Bonneau, M., \& Lebret, B. (2010). Production systems and influence on eating quality of pork. Meat Science, 84, 293-300.

Carrapiso, A. I., Bonilla, F. \& Garcìa, C. (2003). Effect of crossbreeding and rearing system on sensory characteristics of Iberian ham. Meat Science, 65, 623-629.

Carrapiso, A. I., Jurado, A. M., Timòn, M. L., \& Garcìa, C. (2002). Odour-active compounds of Iberian hams with different aroma characteristics. Journal of Agricultural and Food Chemistry, 50, 6453-6458.

Cava, R., Ruiz, J., Ventanas, J., \& Antequera, T. (1999). Oxidative and lipolytic changes during ripening of Iberian hams as affected by feeding regime: Extensive feeding and a-tocopheryl acetate supplementation. Meat Science, 52, 165-172.

Cava, R., Ruiz, J., Ventanas, J., \& Antequera, T. (1999). Effect of $\alpha$-tocopheryl acetate supplementation and the extensive feeding of pigs on the volatile aldehydes during the maturation of Iberian ham. Food Science and Technology International, $5,235-241$.

Cava, R., Ventanas, J., Tejeda, J. F., Ruiz, J., \& Antequera, T. (2000). Effect of free-range rearing and $\alpha$-tocopherol and copper supplementation on fatty acid profiles and susceptibility to lipid oxidation of fresh meat from Iberian pigs. Food Chemistry, $68,51-59$.
Chiofalo, B., Lo Presti, V., Piccolo, D., \& Arena, G. (2007). Nero Siciliano pig: Effect of the diet on meat quality. Italian Journal of Animal Science, 2(Suppl. 1), 679.

Coutron-Gambotti, C., Gandemer, G., \& Casabianca, F. (1998). Effects of substituting a concentrated diet for chestnuts on the lipid traits of muscle and adipose tissues in Corsican and Corsican $\times$ Large White pigs reared in a sylvo-pastoral system in Corsica. Meat Science, 50, 163-174.

Coutron-Gambotti, C., Gandemer, G., Rousset, S., Maestrini, O., \& Casabianca, F. (1999). Reducing salt content of dry-cured ham: Effect on lipid composition and sensory attributes. Food Chemistry, 64, 13-19.

Crovettti, A., Bozzi, R., Nardi, L., Franci, O., \& Fontanesi, L. (2007, May 29-June 1). Assessment of variability of genes associated with meat quality traits in Cinta Senese pigs. Proceedings of the 17th ASPA Congress, Alghero (pp. 101).

d'Acampora Zellner, B., Dugo, P., Dugo, G., \& Mondello, L. (2008). Gas chromatographyolfactometry in food flavour analysis. Journal of Chromatography A, 1186, 123-143.

Diaz, I., Garcia Regueiro, J. A., Casillas, M., \& De Pedro, E. (1996). Triglyceride composition of fresh ham fat from Iberian pigs produced with different systems of animal nutrition. Food Chemistry, 55, 383-387.

Dirinck, P., Van Opstaele, F., \& Vandendriessche, F. (1997). Flavour differences between northern and southern European cured hams. Food Chemistry, 59, 511-521.

Edwards, S. A. (2005). Product quality attributes associated with outdoor pig production. Livestock Production Science, 94, 5-14.

Edwards, S. A. \& Casabianca, F. (1997). Perception and reality of product quality from outdoor production systems in Northern and Southern Europe. Livestock farming systems - More than food production. In J. T. Sorensen (Ed.), EAAP Publication, Vol. 89. (pp. 145-156) Wageningen: Wageningen Pers.

Elias, M., Sanabria, C., \& Tirapicos Nunes, J. (2000). Effet du génotype du régime alimentaire sur quelques caractéristiques physique et chimiques du "Palaio" et du "Jambon de Barrancos". Option Mediterranéennes, 41, 217-225.

Fernàndez, A., Garcìa-Gasco, J., De Pedro, E., Siliò, L., \& Rodriguez, M. C. (2007). Genetic antagonism between intramuscular fat content and primal cuts in Iberian pigs. Option Mediterranéennes, 76, 43-46.

Flores, J. (1997). Mediterranean vs northern European meat products. Processing technologies and main differences. Food Chemistry, 59, 505-510.

Fortina, R., Barbera, R., Lussiana, C., Mimosi, A., Tassone, S., Rossi, A., et al. (2005). Performances and meat quality of two Italian pig breeds fed diets for commercial hybrids. Meat Science, 71, 713-718.

Franci, O., Bozzi, R., Pugliese, C., Acciaioli, A., Campodoni, G., \& Gandini, G. (2005). Performance of Cinta Senese pigs and their crosses with Large White. 1 Muscle and subcutaneous fat characteristics. Meat Science, 69, 545-550.

Franci, O., \& Pugliese, C. (2004, June 10). Issues and perspectives of Italian autochthonous pigs. Proceedings of the 39th Simposio Internazionale di Zootecnia Meat Science E' Research, Rome, Italy (pp. 143-158).

Gandemer, G. (2002). Lipids in muscles and adipose tissues, changes during processing and sensory properties of meat products. Meat Science, 62, 309-321.

Gandemer, G. (2009). Dry cured ham quality as related to lipid quality of raw material and lipid changes during processing: A review. Grasas y Aceites, 60, 297-307.

Garcìa, M., Horrillo, M. C., Santos, J. P., Aleixandre, M., Sayago, I., Fernández, M. J., et al. (2003). Artificial olfactory system for the classification of Iberian hams. Sensors and Actuators B, 96, 621-629.

Garcìa-Gonzáles, D. L., Tena, N., \& Aparicio, R. (2009). Contributing to interpret sensory attributes qualifying Iberian hams from the volatile profile. Grasas y Aceites, 60, 277-283.

Garcìa-Gonzáles, D. L., Tena, N., Aparicio-Ruiz, R., \& Morales, M. T. (2008). Relationship between sensory attributes and volatile compounds qualifying dry-cured hams. Meat Science, 80, 315-325.

Girard, J. P., Bout, J., \& Salort, D. (1988). Lipides et qualités des tissues adipeux et musculaires de porc. Facteur da variation. Journées de la Recherche Porcine en France, 20, 255-278.

Jonsäll, A., Joansson, L., \& Ludström, K. (2001). Sensory quality and cooking loss of ham muscle (M. Biceps femoris) from pigs reared indoors and outdoors. Meat Science, 57, 245-250.

Jurado, Á., Carrapiso, A. I., Ventanas, J., \& Garcìa, C. (2009). Changes in SPME-extracted volatile compounds from Iberian ham during ripening. Grasas y Aceites, 60, 262-270.

Jurado, A., Garcìa, A., Timòn, M. L., \& Carrapiso, A. I. (2007). Effect of ripening time and rearing system on amino acid-related flavour compounds of Iberian ham. Meat Science, $75,585-594$.

Karolyi, D., Luković, Z., \& Salajpal, K. (2007, October 11-13). Production traits of black slavonian pigs. Proceedings of the 6th International Symposium on the Mediterranean Pig, Messina - Capo d'Orlando, Italy (pp. 207-213).

Labroue, F., Goumy, S., Gruand, J., Mourot, J., Neelz, V., \& Legault, C. (2000). Comparaison au Large White de quatre races locales porcines françaises pour les performances de croissance, de carcasse et de qualité de la viande. Journées de la Recherche Porcine en France, 32, 403-411.

Labroue, F., Marsac, H., Luquet, M., Gruand, J., Mourot, J., Neelz, V., et al. (2001). Performances of French local breeds. In L. Ollivier, F. Labroue, P. Glodek, G. Gandini, \& J. V. Delgado (Eds.), Pig genetic resources in Europe (pp. 51-57). Wageningen: Wageningen Pers.

Lambert-Derkimba, A., Verrier, É., \& Casabianca, F. (2011). Tensions entre ressources génétiques locales et ancrage territorial des produits Le cas du porc Nustrale et du projet d'AOP charcuterie de Corse. Economie Rurale, 322, 39-49.

Lebecque, A., Giraud, G., Amblard, C., Lucan, A., \& Poma, J. P. (2007). Analyse des profiles sensoriels de jambons secs français et espagnols. Option Mediterranéennes, 76, 333-337.

Lopez, M. O., de la Hoz, L., Cambero, M. I., Gallardo, E., Reglero, G., \& Ordoñez, J. A. (1992). Volatile compounds of dry cured hams from Iberian pigs. Meat Science, 31, 267-277. 
Lopez-Bote, C. J. (1998). Sustained utilization of the Iberian pig breed. Meat Science, 49, 17-27.

Lopez-Bote, C. J., Toldrà, F., Daza, A., Ferrer, J. M., Menoyo, D., Siliò, L., et al. (2008). Effect of exercise on skeletal muscle proteolytic enzyme activity and meat quality characteristics in Iberian pigs. Meat Science, 79, 71-76.

Madonia, G., Diaferia, C., Moretti, V. M., Margiotta, S., Manganelli, E., Pruiti, V., et al. (2007). Nero Siciliano pigs proposed as a traditional quality product: Comparison between salami made from black pig's meat and white pig's meat. Option Mediterranéennes, 76, 251-257.

Malovrh, S., Planinc, M., \& Kovač, M. (2010, October 14-16). Genetic structure of Krškopolje pig based on pedigree data. Proceedings of the 6th International Symposium on the Mediterranean Pig, Cordoba, Spain (pp. 12).

Martín, L., Córdoba, J. J., Antequera, T., Timón, M. L., \& Ventanas, J. (1998). Effects of salt and temperature on proteolysis during ripening of Iberian ham. Meat Science, 49, $145-153$.

Matassino, D., Davoli, R., Occidente, M., Milc, J., Caiola, G., Rocco, M., et al. (2000). Identificazione del genotipo per la sensibilità all'alotano in alcuni tipi genetici autoctoni. Option Mediterranéennes, 41, 265.

Matos, C. A. P. (2000). Recursos genéticos animais e sistemas de exploração tradicionais em Portugal. Archivos de Zootecnia, 49, 363-383.

Mayoral, A. I., Dorado, M., Guillén, M. T., Robina, A., Vivo, J. M., Vazquez, C., et al. (1999). Development of meat and carcass quality characteristics in Iberian pigs reared outdoors. Meat Science, 52, 315-324.

Muriel, E., Ruiz, J., Ventanas, J., \& Antequera, T. (2002). Free-range rearing increases (n-3) polyunsaturated fatty acids of neutral and polar lipids in swine muscles. Food Chemistry, 78, 219-225.

Neves, J., Freitas, A., Martins, J., \& Nunes, J. (2007, October 11-13). Alpha-tocopherol content on the Semimembranosus muscle of Alentejano pigs reared in intensive and extensive conditions. Proceedings of the 6th International Symposium on the Mediterranean Pig, Messina-Capo d'Orlando, Italy (pp. 165-167).

Pérez-Marín, D., de Pedro Sanz, E., Guerrero-Ginel, J. E., \& Garrido-Varo, A. (2009). A feasibility study on the use of near-infrared spectroscopy for prediction of the fatty acid profile in live Iberian pigs and carcasses. Meat Science, 83, 627-633.

Pérez-Palacios, T., Antequera, T., Durán, M. L., Caro, A., Rodríguez, P. G., \& Ruiz, J. (2010). MRI-based analysis, lipid composition and sensory traits for studying Iberian drycured hams from pigs fed with different diets. Food Research International, 43, 248-254.

Pérez-Palacios, T., Ruiz, J., Tejeda, J. F., \& Antequera, T. (2009). Subcutaneous and intramuscular lipid traits as tools for classifying Iberian pigs as a function of their feeding background. Meat Science, 81, 632-640.

Petrón, M. J., Muriel, E., Timón, M. L., Martín, L., \& Antequera, T. (2004). Fatty acids and triacylglycerols profiles from different types of Iberian dry-cured hams. Meat Science, 68, 71-77.

Pinheiro, I., Godinho, R., Santos Silva, J., Pires da Costa, J., Alves, P. C., \& Ferrand, N. (2007). Identification of genetic polymorphisms at RYR1, PRKAG3 and ESR loci in Portuguese autochthonous pig breeds. Option Mediterranéennes, 76, 67.

Planinc, M., Malovrh, S., \& Kovač, M. (2010, October 14-16). Growth of Krškopolje pigs. Proceedings of the 6th International Symposium on the Mediterranean Pig, Cordoba, Spain (pp. 44).

Porcu, S., Madonia, G., Liotta, L., Margiotta, S., Chiofalo, V., \& Ligios, S. (2007, 29 May-1 June). Physical characteristics of Longissimus lumborum muscle of "Sarda" and "Nero Siciliano" pigs reared outdoor. Preliminary results. Proceedings of the 17th ASPA Congress, Alghero, Italy (pp. 710).

Poto, A., Galián, M., \& Peinado, B. (2007). Chato Murciano pig and its crosses with Iberian and Large White pigs, reared outdoors. Comparative study of the carcass and meat characteristics. Livestock Science, 111, 96-103.

Pugliese, C., Bozzi, R., Campodoni, G., Acciaioli, A., Franci, O., \& Gandini, G. (2005). Performance of Cinta Senese pigs reared outdoors and indoors. 1. Meat and subcutaneous fat characteristics. Meat Science, 69, 459-464.

Pugliese, C., Calagna, G., Chiofalo, V., Moretti, V., Margiotta, S., Franci, O., et al. (2004). Comparison of the performances of Nero Siciliano pigs reared indoors and outdoors. 2. Joints composition, meat and fat traits. Meat Science, 68, 523-528.

Pugliese, C., Sirtori, F., Pianaccioli, L., Franci, O., Acciaioli, A., Bozzi, R., et al. (2006). Effect of rearing system on meat quality and on fatty acid composition of subcutaneous fat in Cinta Senese pigs. In J. M. C. Ramalho Ribeiro, A. E. M. Horta, C. Mosconi, \& A. Rosati
(Eds.), Animal products from the Mediterranean area (pp. 289-293). : Wageningen Academic Publishers.

Pugliese, C., Sirtori, F., Ruiz, J., Martin, D., Parenti, S., \& Franci, O. (2009). Effect of pasture on chestnut or acorn on fatty acid composition and aromatic profile of fat of Cinta Senese dry-cured ham. Grasas y Aceites, 60, 271-276.

Ramos, A. M., Delgado, J. V., Rangel-Figueiredo, T., Barba, C., Matos, J., \& Cumbreras, M. (2000). Genotypic and allelic frequencies of the RYRI locus in the Manchado de Jabugo pig breed. Proceeding of Joint session of EAAP commission on pig production, animal genetics and animal nutrition.

Rey, A. I., Daza, A., Lòpez-Carrasco, C., \& Lòpez-Bote, C. J. (2006). Feeding Iberian pigs with acorns and grass in either free-range or confinement affects the carcass characteristics and fatty acids and tocopherols accumulation in Longissimus dorsi muscle and backfat. Meat Science, 73, 66-74.

Rey, A. I., \& Lòpez-Bote, C. J. (2001). Effect of dietary copper and vitamin E supplementation, and extensive feeding with acorn and grass on Longissimus muscle composition and susceptibility to oxidation in Iberian pigs. Journal of Animal Physiology and Animal Nutrition, 85, 281-292.

Riaublanc, A., Gandemer, G., Gambotti, G., Davenel, A., \& Monin, G. (1999). La détermination de la composition en triglycérides des tissus adipeux. Un outil pour l'identification des jambons secs de haut de gamme en Europe. Journées de la Recherche Porcine en France, 31, 301-307.

Russo, V., Fontanesi, L., Davoli, R., Chiofalo, L., Liotta, L., \& Zumbo, A. (2004). Analysis of single nucleotide polymorphisms in major and candidate genes for production traits in Nero Siciliano pig breed. Italian Journal of Animal Science, 3, 19-29.

Salvatori, G., Filetti, F., Di Cesare, C., Maiorano, G., Pilla, F., \& Oriani, G. (2008). Lipid composition of meat and backfat from Casertana purebred and crossbred pigs reared outdoors. Meat Science, 80, 623-631.

Sirtori, F., Pugliese, C., Parenti, S., D'Adorante, S., \& Franci, O. (2011). Fattening with chestnut in Cinta Senese pigs: Effect on meat and fat characteristics. In R. Bouche, A. Derkimba, \& F. Casabianca (Eds.), New trend for innovation in the Mediterranean production (pp. 117-122). Wageningen: Wageningen Academic Publishers.

Tejeda, J. F., Antequera, T., Martin, L., Ventanas, J., \& Garcìa, C. (2001). The study of the brunched hydrocarbon fraction of intramuscular lipids from Iberian fresh ham. Meat Science, 58, 175-179.

Tejeda, J. F., Gandemer, G., Antequera, T., Viau, M., \& García, C. (2002). Lipids traits of muscle as related to genotype and fattening diet in Iberian pigs: Total intramuscular lipids and triacylglycerols. Meat Science, 60, 357-363.

Tirapicos Nunes, J. L. (2007). Livestock management to optimise carcass and meat characteristics in farming system using natural resources. Option Mediterranéennes, 76, 73-82.

Vicente, A., Pereira, L., Carolino, N., \& Gama, L. T. (2006). Caracterição morfológica do porco "Malhado de Alcobaça". Suinicoltura, 69, 47-49.

Zhang, W., Kuhler, D. L., \& Rempels, W. E. (1992). Halothane gene and swine performance. Journal of Animal Science, 70, 1307-1313.

Zullo, A., Barone, C. M. A., Colatruglio, P., Diaferia, C., Genovino, G., \& Matassino, D. (2007). Sensory evaluation of dry cured coppa in some swine autochthonous genetic type. Option Mediterranéennes, 76, 295-298.

Zullo, A., Barone, C. M. A., Colatruglio, P., Girolami, A., \& Matassino, D. (2003). Chemica composition of pig meat from the genetic type "Casertana" and its crossbreeds Meat Science, 63, 89-100.

Zumbo, A., Di Rosa, A. R., Lo Presti, V., Pruiti, V., \& Piccolo, D. (2007, October 11-13). Analysis of the volatile composition of fresh and seasoned lard in "Nero Siciliano" pigs in relation of fattening diet. Proceedings of the 6th International Symposium on the Mediterranean Pig. Messina - Capo d'Orlando, Italy (pp. 194-197).

Zumbo, A., Lo Presti, V., Di Rosa, A. R., Pruiti, V., Di Marco, V., \& Piccolo, D. (2007, October 11-13). Fatty acid profile of intramuscular fat of "Nero Siciliano" fattening pigs fed with different diets. Proceedings of the 6th International Symposium on the Mediterranean Pig, Messina - Capo d'Orlando, Italy (pp. 224-227).

Zumbo, A., Pugliese, C., Lo Presti, V., Sirtori, F., Piccolo, D., \& Di Rosa, A. R. (2007, October 11-13). Effect o fattening diets on the volatile flavour compound of "Cinta Senese" salami and seasoned lard. Proceedings of the 6th International Symposium on the Mediterranean Pig, Messina - Capo d'Orlando, Italy (pp. 198-202). 